\title{
Teacher design of technology for emergent literacy: An explorative feasibility study
}

Citation for published version (APA):

McKenney, S., \& Voogt, J. (2012). Teacher design of technology for emergent literacy: An explorative feasibility study. Australasian Journal of Early Childhood, 37(1), 4-12. https://doi.org/10.1177/183693911203700102

DOI:

$10.1177 / 183693911203700102$

Document status and date:

Published: 01/03/2012

Document Version:

Peer reviewed version

Document license:

CC BY-SA

Please check the document version of this publication:

- A submitted manuscript is the version of the article upon submission and before peer-review. There can be important differences between the submitted version and the official published version of record. People interested in the research are advised to contact the author for the final version of the publication, or visit the DOI to the publisher's website.

- The final author version and the galley proof are versions of the publication after peer review.

- The final published version features the final layout of the paper including the volume, issue and page numbers.

Link to publication

\section{General rights}

Copyright and moral rights for the publications made accessible in the public portal are retained by the authors and/or other copyright owners and it is a condition of accessing publications that users recognise and abide by the legal requirements associated with these rights.

- Users may download and print one copy of any publication from the public portal for the purpose of private study or research.

- You may not further distribute the material or use it for any profit-making activity or commercial gain

- You may freely distribute the URL identifying the publication in the public portal.

If the publication is distributed under the terms of Article 25fa of the Dutch Copyright Act, indicated by the "Taverne" license above, please follow below link for the End User Agreement:

https://www.ou.nl/taverne-agreement

Take down policy

If you believe that this document breaches copyright please contact us at:

pure-support@ou.nl

providing details and we will investigate your claim.

Downloaded from https://research.ou.nl/ on date: 26 Apr. 2023 
Teacher design of technology for emergent literacy: An explorative feasibility study

Susan McKenney \& Joke Voogt

Affiliation (both authors):

Department of Curriculum Design and Educational Innovation, University of Twente,

Enschede, the Netherlands

Contact details:

Department of Curriculum Design \& Educational Innovation

Faculty of Behavioural Sciences

University of Twente

PO Box 217

7500 AE Enschede

the Netherlands

Office: Cubicus (\#41) C314

Phone: +31 (0)53 4892890

Fax: +31 (0)534893759

Email: susan.mckenney@utwente.nl 


\begin{abstract}
The active participation of teachers in designing classroom learning experiences contributes to teacher abilities to facilitate learning. This paper reports on a case study of one Dutch teacher designing a technology-rich learning environment for emergent literacy. Data were collected to explore the design and implementation of the learning environment, respectively. The main findings from the design study are that scaffolding teacher design: takes mammoth effort; appears to contribute to teacher learning; yields usable products and ownership, both of which seem to contribute to classroom implementation, but also yields products whose subject matter quality is questionable. The pre-post test data from the implementation study indicate that all children working with the intervention exhibited significant learning gains. Based on the findings, it is hypothesized that the high degree of teacher ownership which stems from designing classroom materials positively influences integration of on-computer activities with off-computer classroom activities, and that a high level of integration yields positive influence on pupil learning about the functions of written language. This rich, but small scale study points to the need for more refined understanding of the gap between what teachers have already mastered and what they can achieve when provided with support, when engaging in technology-rich classroom innovation. We therefore call for innovation design to not only meet learner needs, but also to fit explicitly within a teacher's 'technological zone of proximal development'.
\end{abstract}

\title{
Keywords
}

Teacher competencies, technology, curriculum design, emergent literacy

\section{Document count}

Including cover page, labels and references: 7051

\section{Related files}

Figure1.jpg

Table1.doc 


\section{Introduction}

Teachers in general - and of young children in particular - struggle to find and employ pedagogically appropriate technology applications in their classrooms. Building on Schulman's notion of pedagogical content knowledge (PCK), Mishra and Koeler (2006) argue that thoughtful pedagogical uses of technology require the development of complex, situated knowledge, which they refer to as TPCK: technological pedagogical content knowledge. They, and others, advocate that such knowledge be learned, in part, through technology design and implementation (Doering, Veletsianos, Scharber, \& Miller, 2009; Koehler \& Mishra, 2007); as well as reflection on that action (cf. Schön, 1983; 1987; 1996). This paper describes an exploratory study conducted on the benefits and risks of engaging teachers in the design of a technology-rich learning environment that aims to foster the development of early literacy in Dutch kindergarten classrooms. The underlying assumption is that active teacher involvement in learning environment design positively influences the quality of the learning environment as well as its implementation and use.

\section{Early literacy: content and pedagogies}

A pioneer in the field, Clay, (1966) emphasized that literacy begins long before school entry. Underpinning Clay's notion of emergent literacy, which involves synergistic development of listening, speaking, reading, writing and viewing from birth, are several assertions, which have been stressed by other experts, as well. First, well-known theorists have long claimed that children play active roles in their own development, (Bruner, 1983; Piaget, 1952; Piaget \& Inhelder, 1969; Vygotsky, 1962). Clay's position that children are active learners about print long before they can read or write is consistent with this view. Second, Macnamara (1972) argued that language learning is driven by and dependent on the capacity to understand and participate in social situations. This is well-aligned with Clay's view that social interaction is the basis of emergent literacy. Third, Makin \& Whiteman (2006), demonstrate the value of engaging children in discussion around literacy activities. This connects to Clay's suggestion that being read to and talking around reading are particularly important. Finally,-increasing attention is being given to the development of literacy as a social 
practice. This extends the perspective to include not only active, child-centric experiences (central to the notion of emergent literacy) which are socially constructed as discussed above and by others (e.g. Purcell-Gates, 2001) but also (influenced by critical theory) to be more attuned to social justice issues as children interact with text (Makin, Jones Diaz \& McLaughlan, 2007; Makin, Hayden \& Jones Diaz, 2000).

Consistent with the ideas above, the intervention described in this paper embraces the characterization of children's involvement in their own literacy development as active, social and (often) connected to text-related discourse. In addition, Clay's focus on meaning (in the early stages, considered more important than accuracy and conventions) is at the heart of the pedagogical and content areas addressed in the intervention which provided the setting for this study. Central to the intervention is that children create printed texts and use them for authentic purposes and/or for play. Play is widely considered the dominant medium for learning by young children. However, opinions vary substantially when it comes to defining play, its status, and its pedagogies. The last decade in particular has seen an increase in attention to the social and cultural aspects of play; to children as social and active agents in their own play; and to conceptualizations of different forms of play and their educational significance. While several books provide outstanding overviews of these developments (e.g. Moyles, 2005; Wood \& Attfield, 2005), the next section discusses important notions related to this intervention: at the play-literacy interface. Thereafter, salient views are given on the specific area of early literacy related to the intervention for which teachers designed and implemented technology: the functions of written language.

Roskos \& Christie (2001) undertook a critical analysis of studies examining children's literacy development through play. They agreed with the major claims of 12 out of 20 studies, which together, "supplied strong evidence that play can serve literacy by: (a) providing settings that promote literacy activity, skills, and strategies; (b) serving as a language experience that can build connections between oral and written modes of expression; and (c) providing opportunities to teach and learn literacy," (p. 59). Much research literature pertains specifically to the value of what Piaget \& Inhelder (1969) refer to as symbolic play (largely pretend play), in which 
children try out language uses as they act on their environments. Pretend play makes a valuable contribution to early literacy and provides important opportunities to practice and experiment with language and thus skills (Van Scoter, 2008). In addition, research has demonstrated that play settings enriched with literary props yield increases in emergent reading and writing activity during play (Burns, Griffin, \& Snow, 1999; Justice \& Pullen, 2003; Morrow, 1990). This may be attributed to the way in which children explore, manipulate and use objects in (dramatic) play (Neuman \& Roskos, 2005a). According to Vygotsky (2004), a child's play is not simply a reproduction of what he has experienced, but a creative reworking of the impressions he has acquired. Underpinning the intervention described in this article is the conviction that children create and express (linguistic) knowledge and ideas through play, driven by their personal interests and the desire for sharing common understanding with others. Their learning about the functions of language takes place through activities that have personal meaning and value for them.

Van Oers (2007), shares this view, that reading and writing operations should be connected to activities that make sense for the pupils, and in which the resulting actions have personal meaning for the children. In accordance with a Vygotskian perspective, which defines literate activity as a generalised ability of using sign systems for personal and interpersonal use, he emphasizes that language is learned through using it in functional and acceptable ways in socio-cultural practices. Translating this into pedagogical content for teachers, De Haan (2005, p. 53) states, "When teachers give room to children to use language according to their communicative needs in play and in other narrative activities, they may create powerful contexts in which children learn of its literate uses." It is important to note that, just as children learn oral language by using it for authentic purposes, they learn about written language in an environment rich with meaningful messages and functional print, surrounding children with words (Warash, Strong, \& Donoho, 1999).

While these notions may ring true with many early childhood educators today, the last two decades have seen a clear and, in our opinion, disquieting, trend toward a narrowed view of early literacy which focuses predominantly on pre-reading skills. This is often accompanied by instructional practices which, on the surface may seem appropriate for younger children (e.g. cutting, pasting, drawing, singing), but actually 
amount to little more than drill and practice, with limited connection to personal meaning-making. In view of this trend, some experts suggest that intentional instruction in preschool and kindergarten can and should foster the prerequisites for academic skills, but that this should take place by promoting foundational competencies that are 'uniquely preschool' and occur through play (Bodrova, 2008). At the same time, others express concern about a narrowing perception of literacy, and how this is being enacted in the classrooms of young children. In their (2005b) article entitled, "Whatever Happened to Developmentally Appropriate Practice in Early Literacy?" Neuman and Roskos express unease with classroom trends in which, for example, 3 and 4 year olds spend long spans of time learning the alphabet, spelling their names and sounding out first letters in words. They contend that such practices may, "consign children to a narrow, limited view of reading that is antithetical to their long-term success not only in school but throughout their lifetime. In other words, we believe that such instruction might actually undermine, rather than promote, the very goals of improving literacy learning." Not only are the teaching practices subject to criticism, but also the related assessment. As Van Oers (2007, p. 301) puts it, “... in the assessment of children's ability to participate in literacy practices, early years teachers, researchers and policy makers often cling to the old tests of technical reading, spelling, and for the youngest child especially, vocabulary acquisition. It looks as if the practice of literacy is reduced to a limited range of decontextualised performances and tests for the sake of measurability."

Against the backdrop of these trends and concerns, we look at the setting for the study reported here. In the Netherlands, we are grateful to see that the functions of language constitute an important portion of the Dutch national goals for early literacy (Verhoeven \& Arnoutse, 1999), which we perceive can be clustered into three strands. The technical strand includes: linguistic consciousness, alphabetic principles, and technical aspects of reading and writing. The understanding strand relates to: book orientation, story understanding and reading and writing comprehension. Finally, the functional strand pertains to: functions of written language, relationship between spoken and written language and functional reading and writing. Based on our experience, and recent Dutch school-based curriculum innovations (many of which reflect the trend mentioned above), we feel that the functional strand is underrepresented in many Dutch classrooms, and call to reinstate this area of literacy 
practice. The teacher-made technological resources created during the study described here speak to this call.

\section{Technology and early literacy}

The functional strand of early literacy seems under-represented in both classroom practices and in research. Review of the literature on technology for early literacy shows much valuable work related to the aforementioned technical strands and the understanding strands. For example, research has examined the potential for software to offer added-value in learning alphabetic principles and the technical aspects of reading and writing (Segers \& Verhoeven, 2002, , 2005) as well as book orientation and story understanding (M. T. de Jong \& Bus, 2003, , 2004). However, in their comprehensive review of technologies for early literacy, Lankshear and Knoebel (2003) found few studies related to the functions of language, and none specifically addressing the functions of written language, despite the potential the computer holds in this area.

The potential for the computer to promulgate discourse and thereby knowledge creation has been examined across various age ranges (McLoughlin \& Oliver, 1998; Scardmalia, Bereiter, \& Lamon, 1994). In terms of early childhood literacy, studies have shown that properly shaped collaborative use of the computer can contribute to pro-social behaviours, including: lively interactions, shared vocabularies, mutual enjoyment and spontaneous, active off-computer play (Brooker \& Siraj-Blatchford, 2002; Van Scoter, 2008). In such ways, technology can serve as a catalyst for social interaction and contribute positively to fostering early literacy (Van Scoter, 2008). Yet teachers struggle to integrate technology with their classroom cultures (Labbo et al., 2003; Olson, 2000). This situation is exacerbated by a lack of high-quality emergent literacy materials (M. T. de Jong \& Bus, 2003; Segers \& Verhoeven, 2002). Appropriate software for fostering literacy skills in young children should be created in such a way that the learner's previous knowledge is taken into account, involve learners actively and encourage the use of language and the explorative nature and curiosity of young children (Brooker \& Siraj-Blatchford, 2002; Plowman \& Stephen, 2005). In addition computer activities of young learners should be integrated with related classroom activities (Van Scoter, 2008) and embedded in (appropriate) 
pedagogical models for technology applications for young children (Plowman \& Stephen, 2005). The design of pedagogically appropriate technology-rich learning environments that align computer activities with classroom activities can be considered as powerful learning environments (T. De Jong \& Pieters, 2006) for young children.

\section{Teachers as designers}

According to (2007, p. 326), "the teacher's task is to understand the link between different types of learning and different pedagogy and to choose one which is appropriate for the situation. This can be a daunting task on its own, and provides even more challenge when technology is involved. Fisher (2003) examined the experiences of teachers involved in the field trials of on-line curriculum materials for three subject areas. While curriculum development, not teacher development, was the main aim of the project, Fisher's article is dedicated to describing the substantial side effects in terms of teacher professional development. He demonstrates how, through participation in the project, teachers used new technologies, gained confidence in working with them, and developed pedagogical confidence and competence through classroom-based learning and reflection. In a similar vein, the assumption underlying the study presented in this paper is that the added value of active participation of teachers in the design of technology-rich learning environments for early literacy development contributes to the competency of teachers to implement such learning environments, as well as increased ownership resulting in more practical, relevant \& accepted innovations.

\section{About the intervention: PictoWriting}

PictoWriting has been developed to support activities in the functional strand of the Dutch national goals for early literacy. PictoWriting is a technology-rich learning environment that uses Clicker® software together with off-computer classroom applications to help emergent readers learn the functions of written language. Shown in Figure 1, the Clicker interface has a 'document' area (top) and a 'composition' area (bottom). Using this visual word processor, children compose texts by clicking on word-image buttons in the composition area, which changes as children progress 
through an activity. The clicked-upon word-image combinations sent to the 'document' area, which remains stable throughout an activity.

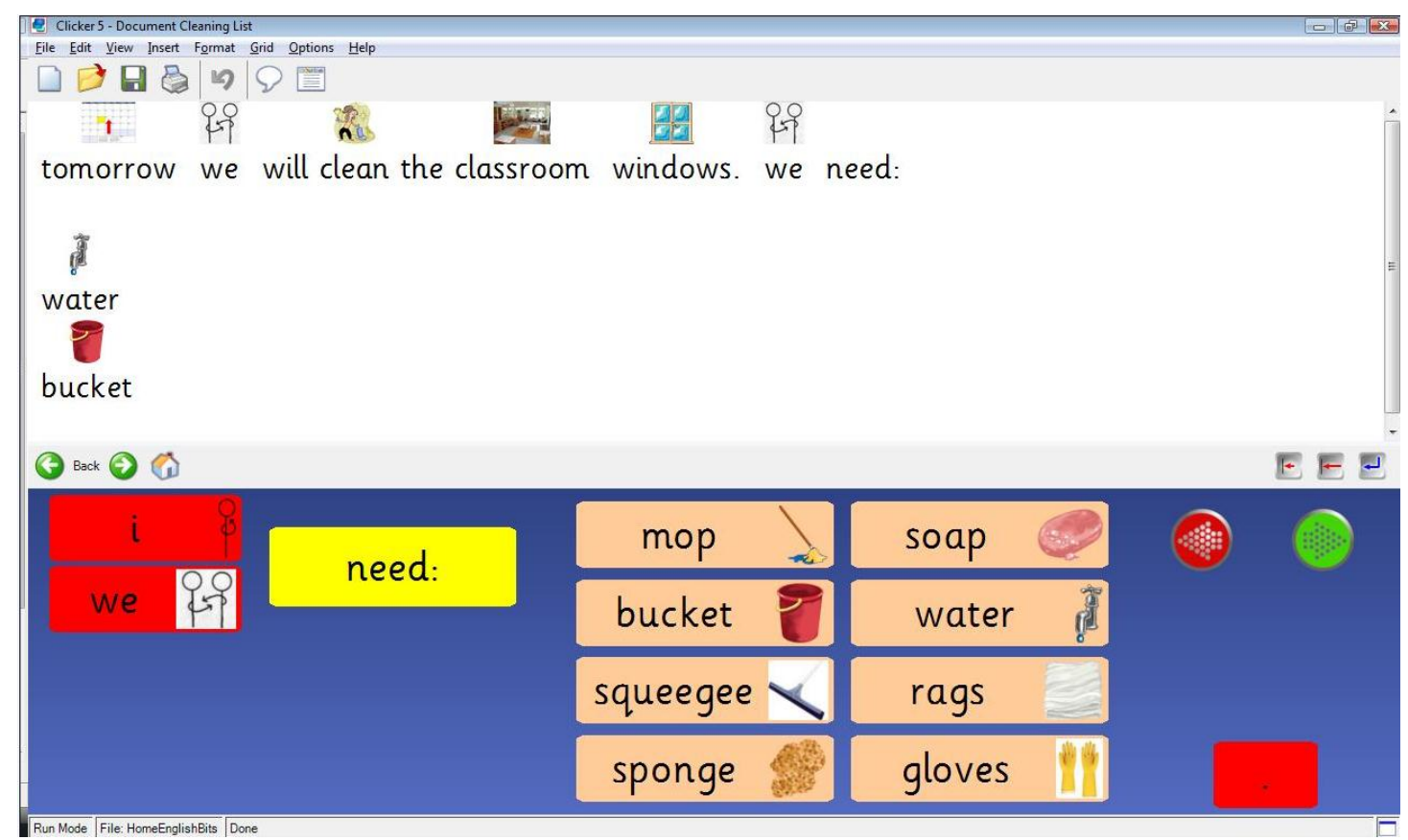

Figure 1. Clicker® screen containing a typical PictoWriting writing activity

An essential characteristic of the software is that teachers can easily adapt or develop the 'composition' area, scaffolding children's composition through single or multiple clickable grids of word-image combinations. A benefit of teachers structuring the content of the writing, is that they can tailor the content to integrate well with ongoing classroom activities and themes, through authentic uses or dramatic play. For example: letters are composed, printed and mailed; grocery lists are compiled and 'used' to shop in a grocery store corner in the classroom; children's stories are printed and bundled in a book for the reading corner. This exploratory study examined teacher design of the clickable grids in the composition area of Clicker.

\section{Research approach}

\section{Questions}

This exploratory study centred on the feasibility of teacher-designers for technologyrich learning environments. Three main areas were addressed, as illustrated through the research questions: 
- What are teacher attitudes toward developing PictoWriting materials?

- What supports are needed for teachers to create PictoWriting materials?

- What learning gains result from using teacher-made materials?

\section{Methods}

This study featured a case study of one teacher designing materials as well as a prepost test experiment to assess learning gains when the teacher-made materials were implemented. Case study data were collected through observations of teacherdesigner sessions; interviews before, during and after the project; and analysis of the PictoWriting materials that were created. The small-scale pre-post test study involved an experimental $(n=7)$ and a control $(n=7)$ group.

\section{Participants}

The teacher, referred to here as Annette, and pupils involved in this study had not previously been engaged in PictoWriting work. The participating school has approximately 200 pupils and is located in a medium-sized city in the Netherlands. About $20 \%$ of the pupil population is Dutch, about $60 \%$ are Turkish immigrants, and the remaining $20 \%$ are immigrants of varied origin. Located in a working-class neighbourhood, this school maintains a shared bank of computers in the hallway as well as two computers per classroom. All computers have access to the local area network (LAN) and Internet. A technology coordinator is present three days a week; while she mostly works directly with children from each grade level she does occasionally provide support to teachers in their use of technology.

\section{Instruments}

The observation data were collected through a semi-open instrument designed specifically for this case study, to capture teacher attitudes and their needs for support. The following aspects of teacher attitudes were studied: involvement, enthusiasm, curiosity, explorativeness, help-neediness, insecurity, nervousness. Supports were divided into three areas: technical, pedagogical and organizational. Technical aspects were clustered according to the resource being used: Clicker®, Internet and the 
school's local area network (LAN). Pedagogical aspects were defined in terms of: structuring the Clicker® grids, length and structure of sentences and use of images. Organizational aspects examined related to planning the design work and planning for implementation of the designed materials. The initial interview was intended to gain the teacher's self-perception of her attitudes toward technology use, as well as her technical, pedagogical and organizational skills. The interviews during and after the intervention were used to check and clarify observational data. Additionally, the teacher-made grids were analysed for indirect indicators of needs for technological and pedagogical support. Finally, alongside the implementation of teacher-made materials, a pre- and post-test were given to experimental and control groups to measure early literacy skills development. In accordance with the PictoWriting goals, the test items were based on the interim standards for early literacy that focused on the nature and function of written language. Nine test items relate to using written language for communicative purposes; four items relate to the functions of printed language; two items pertain to the relationship between written and spoken language; and two items address language consciousness. The reliability of the test was acceptable (Chronbach's alpha $=0.87)$.

\section{Procedures}

The PictoWriting intervention enjoyed the full support of the school's administration, and was eagerly received by most of the kindergarten teachers. A hands-on workshop was held for the kindergarten teachers $(n=6)$ to illustrate how to use Clicker® (from a child's perspective), and to teach how Clicker ${ }^{\circledR}$ materials can be created and adapted (from a teacher's perspective). Teachers were given guidebooks and a coach to assist in creating PictoWriting materials. Within two weeks, the team decided that the PictoWriting work required more time than their planning periods would allow. Because they did not perceive it feasible to grant release time to the whole team, they chose to enable one teacher to focus on the PictoWriting work. This teacher was granted a half-day of release time each week, for five weeks. She worked intensely with the aforementioned coach, and kept her colleagues up to date on her progress through informal communications. The observations took place during the five halfday sessions, while she worked on the PictoWriting materials. Once the materials were completed, they were loaded onto the hallway computers. Children were divided 
into experimental and control groups; and the groups were matched for age, gender, language skills (based on a national language test for kindergarteners) and remediation offered. The experimental group worked once a week with PictoWriting, completing both on- and off-computer activities, for eight weeks in total.

\section{Results}

The preliminary interview revealed that the case study teacher had a very positive attitude toward the use of technology. She was excited about the PictoWriting project and eager to get started. She considered her technical, pedagogical and organizational skills to be average.

\section{Attitude}

Seven aspects related to teacher attitude were examined during each of the five materials design sessions: involvement, enthusiasm, curiosity, explorativeness, helpneediness, insecurity, nervousness. The findings are summarized below. Throughout the PictoWriting design sessions, Annette's involvement remained extremely high. In earlier weeks, her ability to concentrate was quite compromised as she had to work in the noisy computer hallway where children and colleagues often caused interruptions. Once she was given a quiet office in which to work, her concentration improved. Annette was very enthusiastic during the one-on-one sessions. In her free time, she continued to work on the materials and, though Internet, got in touch with another person working developing materials for use with Clicker®. The realization that she was not a lone pioneer in this work, and that others struggle with it positively influenced her attitude. Communications with others making Clicker® materials kept Annette's curiosity high, to the point of distraction. She became so curious about the work of others that she spent precious development time exploring Clicker® materials on the Internet instead of working on her own materials. Despite her curiosity with regard to others' work, Annette did not explore the Clicker ${ }^{\circledR}$ program much in the first half of her work. When she ran into difficulties, she would not try to solve problems herself, but preferred to ask for help. In the last few weeks, she demonstrated cautious experimentation with the program, in attempts to rediscover functions that she had used previously. At no point did she click around the interface 
to see what would happen. Annette did not make use of the guidebook that had been developed specifically for this school's kindergarten team. Rather, she preferred to ask questions to the coach. Sometimes she would note the answers to the questions in a separate notebook, and occasionally those notes would be revisited. Despite the fact that the computer work was challenging for Annette and problems occurred during her work, she did not seem insecure at all. Her perseverance was remarkable. Further, her self-confidence and acceptation of problems appear to have contributed to her motivation. While she was not insecure, Annette did grow nervous at times. She appreciated the one-on-one help of the coach, but felt watched by him at the same time. When he worked next to her and only responded to her concerns, she seemed more at ease. On the other hand, Annette did report feeling stimulated by having someone watch her design activities so closely. On the whole, her attitude toward the work and its facilitation was quite positive, and the interest and support she received appeared to motivate her in a positive way.

\section{Technical support}

Aspects of technical support were clustered according to the resource being used: Clicker ${ }^{\circledR}$, Internet and the school's LAN. Annette did not have an intuitive sense of how the Clicker® program worked. She did not seem to grasp the underlying logic of the software, and as a result, could not extrapolate functions or manipulations. For example, the same control panel is used for deleting and adding word cells. It took Annette a very long time to grasp the control panel function. Until then, even if she remembered how to add a word cell, she could not deduce that she should go back to the same control panel to delete it. Instead, she mainly memorized a limited number of manipulations. A great deal of support was required to help her memorize steps, and eventually gain insight into the program structure. Annette had received the suggestion to design paper-based prototypes in the initial stages, and no support was necessary for this. A paper-based prototype was made for each Clicker grid, and Annette experienced this as an important part of the design process. With much practice, translation of the paper-based prototype into digital materials became easier over time. As is the case for many Dutch kindergarten teachers, Annette is moderately fluent in English. Since the program has an English interface, this was problematic at the start of the Clicker sessions, since labels were not always self-explanatory. Within 
a few sessions, the functions of most buttons had been learned. Annette had little difficulties using Internet in association with the materials development, for example, to locate clip art that could be incorporated. She enjoyed it so much in fact, that, in the eyes of her coach, she spent too much of the valuable development time looking for images. The school's LAN hosts different disk drives for teachers and students. For Annette, this meant that her digital files needed to be kept in the teacher area while she was working on them, and would have to be moved to the learner area once they were completed. Along with the core Clicker® files, all images and media files must also reside in certain locations, for them to be accessed during use of the materials. Proper file management thus requires a basic understanding of network directory structures. Her many detailed notes to herself about how to execute these kinds of manipulations, implied that Annette did not have a sense of this at all. She required sustained assistance with saving, copying and deleting files, which only marginally faded throughout the course of the design work.

\section{Pedagogical support}

Pedagogical aspects were defined in terms of: structuring the Clicker ${ }^{\circledR}$ grids, length and structure of sentences and use of images. Annette proved extremely creative in thinking up activities around the theme that had been selected: housing. No support was necessary in this regard. During Clicker ${ }^{\circledR}$ grid design, Annette required support for making the interface self-explanatory to children. Guidelines were given such as: Be sure to structure the work from left to right; and If children must choose one of several words, give all those word-cells the same colour so that they learn to build sentences by selecting one of each colour. Annette seemed more so focused on her technical work that she forgot to apply some of her pedagogical knowledge to grid design. For example, before the project started, she had indicated that sentences should be kept short and clear. Yet she designed long, complex sentences, occasionally containing errors. When these issues were pointed out to her, she adjusted them accordingly. Ideally, most of the word-cells in the Clicker® materials would have contained images. Since some terms and concepts are difficult to link with an image, facilitating this word-image link requires some forethought. Annette did not seem to consider the use of images as she designed sentences. 


\section{Organizational support}

Organizational aspects examined related to planning the design work and planning for implementation of the designed materials. On her own, Annette gave very little attention to planning the design work. Following initial brainstorming, her own approach was to jump into elaborating one idea; the following week, she seemed to jump into another. At no point did she take initiative to, for example: plan out a total set of materials, budget time, match activities to different literacy goals. However, Annette did give attention to planning for the implementation of the designed materials. After concluding that she would not be able to offer sufficient guidance to children during the on-computer sessions in her classroom, she and a research assistant established a network of parent volunteers to work with small groups of children during the eight weeks of Clicker® activities.

\section{Early literacy skills}

The children in Annette's class were divided into experimental and control groups. The experimental group worked with PictoWriting once a week for two months, the control group did not. In contrast to the control group, a large learning gain was found for the experimental group, as shown in Table 1. Using the Mann-Whitney U test, a significant difference in learning gains was determined for the experimental versus the control group $(\mathrm{Z}=-2.256, \mathrm{P}<.024)$. The effect size for the experimental group was considerably higher compared to the control group. This implies that the on- and off computer activities designed by Annette improve emergent reading and writing skills. However, the extremely small scale of the experiment must be noted.

Table 1: Mean scores (M), standard deviation $(S D)$ of pre-and post-test scores, learning gain and effect size on the Early Literacy Skills Test of the experimental and control group

\begin{tabular}{llllll}
\hline & N & $\begin{array}{l}\text { Pre test } \\
\text { M(SD) }\end{array}$ & $\begin{array}{l}\text { Post test } \\
\text { M(SD) }\end{array}$ & $\begin{array}{l}\text { Learning } \\
\text { gain M(SD) }\end{array}$ & $\begin{array}{l}\text { Effect size } \\
\text { Cohen's d }\end{array}$ \\
\hline $\begin{array}{l}\text { Experimental } \\
\text { condition }\end{array}$ & 7 & $0.68(0.20)$ & $0.96(0.21)$ & $0.27(0.64)$ & 1.36 \\
Control condition & 7 & $0.55(0.31)$ & $0.60(0.24)$ & $0.05(0.20)$ & 0.18 \\
\hline
\end{tabular}




\section{Conclusions}

\section{What are teacher attitudes toward developing Picto Writing materials?}

Annette had a positive attitude toward developing PictoWriting materials. While she exhibited a high degree of involvement throughout the project, this improved when she was given a quiet office in which to work. Her enthusiasm remained high and she continued to work on PictoWriting materials in her free time. While she was curious about other Clicker® materials available, she did not demonstrate curiosity about learning how Clicker worked. Although program help and a specially-made guidebook were available, she clearly preferred to ask her coach for assistance. Annette's awareness of her own challenges in using the program did not dampen her self-confidence. She found the one-on-one coaching to be both motivating and at times it made her feel self-conscious.

\section{What supports are needed for teachers to create PictoWriting materials?}

While she seemed adept at using the Internet, Annette lacked an intuitive sense of how the Clicker and network directory structures worked. As a result, she required a large degree of coaching on the use of these. The way she took notes and referred to them suggests that she memorized how to complete certain tasks, but that she probably did not grasp the underlying logic. While Annette was bursting with creativity in terms of on- and off-computer activities, she seemed to lose touch with her own pedagogical content knowledge. When, for example, it was pointed out to her that she had designed (overly) complex sentences for the children, she adjusted them accordingly. However, at no time did her behaviour indicate that she was thinking ahead in terms of image-word links, learning goals to be met, or distribution of different text types across the set of materials. During the development of materials, this point was not discussed with her (because support was given on a reactive basis, and we wanted to explore what she did of her own accord). After the study, she indicated that merely getting the task completed was a major achievement, and that better linkages (with e.g. learning goals) would have been too big a step to take all at once. 


\section{What learning gains result from using teacher-made materials?}

A substantial increase in pupil learning was found for the experimental group - the group of children who used the PictoWriting materials that had been designed by Annette. This suggests that the PictoWriting on-computer activities designed by Annette, and the classroom applications that followed, contributed to children's understanding of the functions of written language.

\section{Discussion}

Although contextual traditions vary, teachers designing curriculum resources is considered a relatively new phenomenon (Carlgren, 1999). The potential of this work for contributing to teacher learning and also increasing the practicality of a design has been acknowledged (Fisher, 2003; Ben-Peretz, 1990). However, it has been noted that teachers generally require support to do so (McKenney, 2005). The results from this study support the notions from the literature that teachers require, and in fact are entitled to, support for designing interventions. Annette reports that she learned from the curriculum design process. The products were usable and her strong ownership may have contributed to the smooth implementation of the teacher-made materials. However, the linguistic content of the products was not optimal and the supportive effort required to realize the materials development was great. Aside from its limited practicality, the one-on-one coaching model worked well. This approach has been deemed useful in previous literature (Bitner \& Bitner, 2002) and shares some commonalities with the notion of 'cognitive apprenticeship' (Collins, Brown, \& Newman, 1989), which emphasizes that active knowledge construction in context contributes to advanced thinking and learning. As has been observed in other intense programs, the teacher did gain 'digital confidence' (cf. Campbell \& Scotellaro, 2009).

The children's learning gains from use of the teacher-designed PictoWriting materials were significant. Because the quality of the on-computer materials remained questionable, we hypothesize that the learning gains were additionally influenced by the classroom implementation and integration with off-computer activities. However, because this study focused primarily on teacher design of the on-computer materials, no data were collected during the off-computer use of the children's texts. Therefore, attention to the classroom uses of children's printed products warrants additional 
study. Additionally, further research is needed to assess if Annette's experiences are representative; and to better understand how to scaffold PictoWriting materials development in light of pending trade-off decisions regarding practical yet effective support.

Using technology with young children in meaningful ways requires technological pedagogical content knowledge, in this case, related to 4 and 5 year old perceptions of functions of language. Toward developing such knowledge, this study explored the benefits and risks of one approach to engaging teachers in the design of a technologyrich learning environment for early literacy. While the learning gains of pupils using the teacher-made materials suggest promise, the case study data clearly show that substantial targeted support is necessary to help develop this kind of complex and situated knowledge. This study has demonstrated how, even for the most technologically savvy of the group, technological skill limitations can interfere with pedagogical choices. Moreover, it demonstrates how one teacher, who could see pedagogical and content shortcomings in other materials, remained (even after 8 weeks of intense coaching) blind to the same in her own work. So despite the pupil learning gains, we view this as a sign that the technological pedagogical content knowledge necessary to develop the PictoWriting materials in was insufficiently developed throughout the course of this study.

Future efforts to develop such technological, pedagogical content knowledge should include a more nuanced assessment of the gap between what teachers have already mastered and what they can achieve when provided with support. It should also take into consideration the nature and level of support that can be made available, both initially and in the long run. In terms of designing and implementing technology-rich classroom innovation, this means that innovation design should not only be shaped by what the learners need, or what the teachers perceive as useful, but also by what teachers are able to accomplish with support. From this perspective, we recommend that technology-rich classroom innovations be designed to include the support teachers need and deserve so that they may work and learn within their own 'technological zone of proximal development'. 


\section{Acknowledgements}

The authors are grateful to Tjeerd van Berlo and Andrea Althanning for their contributions to the research reported here. 


\section{References}

Bitner, N., \& Bitner, J. (2002). Integrating technology into the classroom: Eight keys to success. Journal of Technology and Teacher Education, 10(1), 95-100.

Bodrova, E. (2008). Make-believe play versus academic skills: a Vygotskian approach to today's dilemma of early childhood education. European Early Childhood Education Research Journal, 16(3), 357 - 369.

Brooker, L., \& Siraj-Blatchford, J. (2002). 'Click on Miaow!': how children of three and four years experience the nursery computer. Contemporary Issues in Early Childhood, 3(2), 251-273.

Bruner, J. (1983). Child's Talk. New York: W. W. Norton.

Burns, M., Griffin, P., \& Snow, C. (1999). Starting out right: A guide to promoting children's reading success. Washington, DC: National Academy Press.

Campbell, A. \& Scotellaro, G. (2009). Learning with technology for pre-service early childhood teachers. Australasian Journal of Early Childhood (34) 2, 11-18.

Carlgren, I. (1999). Professionalism and teachers as designers. Journal of Curriculum Studies, 31(1), 43-56.

Clay, M. (1966). Emergent Reading Behaviour. Unpublished doctoral dissertation, University of Auckland, New Zealand.

Collins, A., Brown, J., \& Newman, S. (1989). Cognitive apprenticeship: Teaching the crafts of reading, writing and mathematics. In L. Resnick (Ed.), Knowing, learning and instruction: Essays in honor of Robert Glaser (pp. 453-494). Hillsdale, NJ: Lawrence Earlbaum Associates.

de Haan, D. (2005). Social pretend play: Potentials and limitations for literacy development. European Early Childhood Education Research Journal, 13(1), $41-55$.

de Jong, M. T., \& Bus, A. G. (2003). How Well Suited are Electronic Books to Supporting Literacy? Journal of Early Childhood Literacy, 3(2), 147-164.

de Jong, M. T., \& Bus, A. G. (2004). The Efficacy of Electronic Books in Fostering Kindergarten Children's Emergent Story Understanding. Reading Research Quarterly, 39(4), 378-393.

De Jong, T., \& Pieters, J. (Eds.). (2006). The design of powerful learning environments (2nd ed.). London: Lawrence Erlbaum Associates. 
Doering, A., Veletsianos, G., Scharber, C., \& Miller, C. (2009). Using the Technological, Pedagogical, and Content Knowledge framework to design online learning environments and professional development. Journal of Educational Computing Research, 41(3), 319-346.

Fisher, T. (2003). Teacher professional development through curriculum development: teachers' experiences in the field trialling of on-line curriculum materials. Technology, Pedagogy and Education, 12(3), 329-343.

Justice, L. M., \& Pullen, P. C. (2003). Promising Interventions for Promoting Emergent Literacy Skills: Three Evidence-Based Approaches. Topics in Early Childhood Special Education, 23(3), 99-113.

Koehler, M., \& Mishra, P. (2007). Tracing the development of teacher knowledge in a design seminar: Integrating content, pedagogy, \& technology. Computers \& Education, 49(3), 740-762.

Labbo, L., Leu, D., Kinzer, C., Teale, W., Cammack, D., Kara-Soteriou, J., et al. (2003). Teacher wisdom stories: Cautions and recommendations for using computer-related technologies for literacy instruction. The Reading Teacher, 57(3), 300-304.

Lankshear, C., \& Knoebel, M. (2003). New technologies in early childhood literacy research: A review of research. Journal of Early Childhood Literacy, 3(1), 5982.

Macnamara, J. (1972). Cognitive basis of lanaugage learning in infants. Psychological Review, 79, 1-12.

Makin, L., Hayden, J., \& Jones Diaz, C. (2000). High quality literacy programs in early childhood classrooms: An Australian case study. Childhood Education, 76(6), 368-373.

Makin, L., Jones Díaz, C., \& McLaughlan, C. (2007). Literacies in childhood: changing views, challenging practice (2nd Ed). Sydney: Elsevier.

Makin, L., \& Whiteman, P. (2006). Young children as active participants in the investigation of teaching and learning. European Early Childhood Education Research Journal, 14(1), 33 - 41.

McKenney, S. (2005). Technology for Curriculum and Teacher Development: Software to Help Educators Learn while Designing Teacher Guides. Journal of Research on Technology in Education, 28(2), 167-190. 
McLoughlin, C., \& Oliver, R. (1998). Maximising the language and learning link in computer learning environments. British Journal of Educational Technology, 29(2), 125-136.

Mishra, P., \& Koehler, M. (2006). Technological Pedagogical Content Knowledge: A Framework for Teacher Knowledge. Teachers College Record, 108(6), 10171054 .

Morrow, L. (1990). Preparing the classroom environment to promote literacy during play. Early Childhood Research Quarterly, 5, 537-544.

Moyles, J. (Ed.). (2005). The Excellence of Play (2 ed.). Maidenhead: Open University Press.

Neuman, S. B., \& Roskos, K. (2005a). The state of state pre-kindergarten standards. Early Childhood Research Quarterly, 20(2), 125-145.

Neuman, S. B., \& Roskos, K. (2005b). Whatever happened to developmentally appropriate practice in early literacy? Young Children, 60(4), 22-26.

Olson, J. (2000). Trojan horse or teacher's pet? Computer and the culture of the school. Journal of Curriculum Studies, 32, 1-8.

Piaget, J. (1952). The Origins of Intelligence in Children. New York: W. W. Norton.

Piaget, J., \& Inhelder, B. (1969). The psychology of the child. New York: Basic Books.

Plowman, L., \& Stephen, C. (2005). Children, play and computers in pre-school education. British Journal of Educational Technology, 36(2), 145-157.

Purcell-Gates, V. (2001). Emergent Literacy Is Emerging Knowledge of Written, Not Oral, Language. New directions for child and adolescent development, 92(Summer), 7-22.

Reunamo, J., \& Nurmilaakso, M. (2007). Vygotsky and agency in language development. European Early Childhood Education Research Journal, 15(3), $313-327$.

Roskos, K., \& Christie, J. (2001). Examining the play-literacy interface: A critical review and future directions. Journal of Early Childhood Literacy, 1(1), 5989.

Scardmalia, M., Bereiter, C., \& Lamon, M. (1994). The CSILE Project: Trying to bring the classroom into World 3. ). In K. McGilly (Ed.), Classroom lessons: Integrating cognitive theory and classroom practice (pp. 201-228). Cambridge, MA: MIT Press/Bradford Books. 
Schön, D. (1983). The reflective practitioner: How professionals think in action. New York: Basic Books.

Schön, D. (1987). Educating the reflective practitioner. San Francisco: Jossey-Bass.

Schön, D. (1996). Reflective conversation with materials. In T. Winograd, J. Bennett, L. Eroung \& B. Hartfield (Eds.), Bringing design to software (pp. 171-184). New York: Addison-Wesley.

Segers, E., \& Verhoeven, L. (2002). Multimedia support of early literacy learning. Computers in Education, 39(3), 207-221.

Segers, E., \& Verhoeven, L. (2005). Long-term effects of computer training of phonological awareness in kindergarten. Journal of Computer Assisted Learning, 21, 17-27.

van Oers, B. (2007). Helping young children to become literate: the relevance of narrative competence for developmental education. European Early Childhood Education Research Journal, 15(3), 299 - 312.

Van Scoter, J. (2008). The Potential of IT to Foster Literacy Development in Kindergarten. In J. V. Knezek (Ed.), International Handbook of Information Technology in Education (pp. 149-161). London: Springer.

Verhoeven, L., \& Arnoutse, C. (Eds.). (1999). Tussendoelen beginnende geletterdheid: Een leerlijn voor groep 1 tot en met 3. Nijmegen: Expertisecentrum Nederlands.

Vygotsky, L. (1962). Thought and language. Cambridge, MA: MIT Press. Vygotsky, L. (2004). Imagination and creativity in childhood. Journal of Russian and East European Psychology, 42(1), 7-97.

Warash, B., Strong, M., \& Donoho, R. (1999). Approaches to environmental print with young children. In O. G. Nelson \& W. M. Linek (Eds.), Practical classroom applications of language experience: Looking back, looking forward (pp. 53-58). Boston, MA: Allyn \& Bacon.

Wood, E., \& Attfield, J. (2005). Play, learning and the early childhood curriculum. London: Sage. 